\title{
低温での氷一デンプン糖混合系の交流絶縁破壊特性
}

\author{
村上 祐一 ${ }^{* 1, \dagger}$ ，三田井 佑樹 ${ }^{* 1}$, 村本 裕二*1
}

\section{AC Breakdown Properties of Ice-Starch Sugar Mixed System in Low Temperature}

\author{
Yuichi MURAKAMI ${ }^{* 1, \dagger}$, Yuki MITAI ${ }^{* 1}$ and Yuji MURAMOTO* ${ }^{* 1}$
}

\begin{abstract}
Synopsis: This paper reports the AC breakdown characteristics of an ice-starch sugar mixed system under $\mathrm{LN}_{2}$. We observed the AC breakdown voltage and solidification state of the ice-starch sugar mixed system. These results were shown as follows: (i) the AC breakdown voltage of a 15 20 wt \% starch sugar sample under $\mathrm{LN}_{2}$ is higher than that of $0 \mathrm{wt} \%$ (only ice) and $100 \mathrm{wt} \%$ (only starch sugar). (ii) the AC breakdown voltage of ice-starch sugar samples does not depend on the cooling speed and freezing time under $243 \mathrm{~K}\left(-30^{\circ} \mathrm{C}\right)$ or $193 \mathrm{~K}\left(-80^{\circ} \mathrm{C}\right)$ cooling. (iii) the $0 \mathrm{wt} \%$ starch sugar sample (only ice) has many visible voids, but the number of visible voids decreases with the increase of the starch-sugar concentration.
\end{abstract}

Keywords: AC breakdown characteristics, Ice, Starch sugar

(Some figures in this article may appear in color only in the electronic version)

\section{1. はじめに}

様々な電力問題を解決するために，超電導技術の適用が 期待されている。たとえば，核融合炉では超電導マグネッ ト, 電力送電では超電導ケーブル等が開発されてきた。こ れらの超電導機器は極低温下で使用されるため, それらの 環境に耐えられる材料が必要となり，今日までにさまざま な材料が開発されてきた。環境負荷低減の意識も高まって おり，我々の身近なモノも環境に優しい材料が使われ始め てきた。超電導マグネットの電気絶縁材料には，機械的強 度や電気絶縁性能の高い GFRP（ガラス䋊維強化プラス チック）が用いられている 1)。GFRP の厚さは数 $\mathrm{mm}$ 数 十 $\mathrm{mm}$ 程度であり, これによりコイルとコイルケース間を 絶縁する。発生する電圧は $15 \mathrm{kV}$ 程度であり，高い絶縁性 能が要求される 1)。しかし, GFRP はガラス繊維とプラス チックの複合材料のため, 自然に分解されないことから, GFRP は環境負荷が大きい2)。そのため，低環境負荷の極 低温電気絶縁材料の開発が期待されている。

水は環境に優しい材料として注目されている。氷単体の 電気物性等に関しては, Peter V. Hobbs 氏の Ice Physics ${ }^{3)}$

Received July 21, 2021

*1 名城大学理工学部

于468-8502 愛知県名古屋市天白区塩釜口 1-501

Department of electrical and Electronic Engineering, Meijo

University, 1-501 Shiogamaguchi, Tempaku-ku, Nagoya, Aichi

468-8502, Japan

† E-mail: myuichi@meijo-u.ac.jp

DOI: $10.2221 /$ jcsj. 56.356
前野紀一氏の水の科学 4)に詳細に䌂められている。誘電絶 縁分野では, 水単体あるいは氷複合系による極低温絶縁材 料の開発が取り組まれてきた ${ }^{5,6)}$ 。これまでに本研究室も, GFRP に替わる極低温の低環境負荷材料 7)として, 水に着 目してきた。そして, 水一ケナフ繊維複合系 ${ }^{8)}$, 水一竹繊 維複合系 ${ }^{9)}$, 水一アルコール複合系 ${ }^{10,11)}$, および固化アル コール—綿布複合系 ${ }^{12)}$ の交流絶縁破壊特性が GFRP に匹敵 することを報告してきた。水溶性であるアルコールと蒸留 水の混合物により, 絶縁破壊特性が向上したことから, 本 研究では, 水溶性物質である多糖類の水あめ(デンプン糖) に注目した。水あめは食用のものであり, 安価で入手が容 易, そして安全である。今回は, この水一デンプン糖混合 系の交流絶縁破壊電圧のデンプン糖濃度特性を取得し, 水 一デンプン糖混合系の冷却速度および固化状態の関係を調 査したので報告する。

\section{2. 実験方法}

本研究では, 食用の水あめ(株式会社スドージャム)をデ ンプン糖として用いた。実験試料は, デンプン糖と水の混 合液であり，デンプン糖濃度は $0 \sim 25$ wt $\%$ である。Fig. 1 に本研究での絶縁破壊実験で使用した球一平板電極を示す。 球電極の半径は $12.7 \mathrm{~mm}$ であり, 電極間距離は $0.3 \mathrm{~mm}$ で ある。この電極間に試料 $1 \mathrm{~mL}$ を注入した。電極系内に入 れた試料は, $243 \mathrm{~K}\left(-30{ }^{\circ} \mathrm{C}\right)$ 冷凍庫(日本ゼネラル・アプ ラィアンス株式会社 $\mathrm{HNC100)および} 193 \mathrm{~K}\left(-80^{\circ} \mathrm{C}\right)$ の冷凍 庫(日本フリーザ株式会社 MY BIO VT シリーズ)により 凍結させた。Fig. 2 に交流絶縁破壊実験回路を示す。それ 
ぞれの冷凍庫で凍結させた試料を液体窒素 $\left(77 \mathrm{~K}\right.$ ：-196 $\left.{ }^{\circ} \mathrm{C}\right)$ 内に浸漬し, 液体窒素下にて破壊実験を実施した。印加電 圧は交流ランプ電圧（周波数 $60 \mathrm{~Hz}$ ，電圧上昇率 $1 \mathrm{kVrms} / \mathrm{s}$ ) である。電圧印加時において, 試料間の電位差をディジタ ルオシロスコープ (Tektronix DPO 4034) および高圧プ ローブ (Tektronix P6015A) を用いて測定し, 電位差がな くなった(絶縁破壞)時の電圧を絶縁破壊電圧とした。Fig. 3 に試料の絶縁破壊直後の破壊痕を示す。沿面放電により 電位差がなくなることもあるので, Fig. 3 に示すように破 壊痕が電極間に存在すること確認し, 試料の交流絶縁破壊 電圧を測定した。

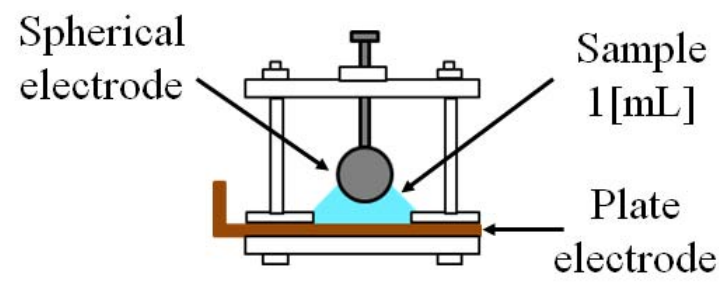

Fig. 1 Spherical - plate electrodes system.

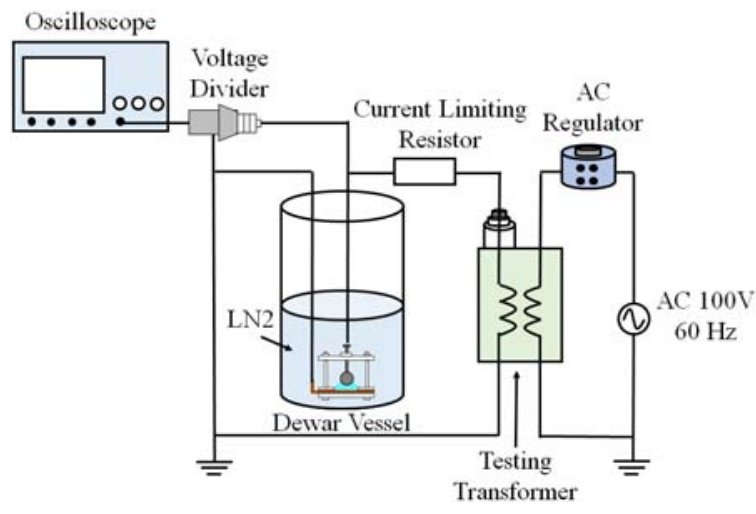

Fig. 2 Experimental Circuit for AC Breakdown Test.

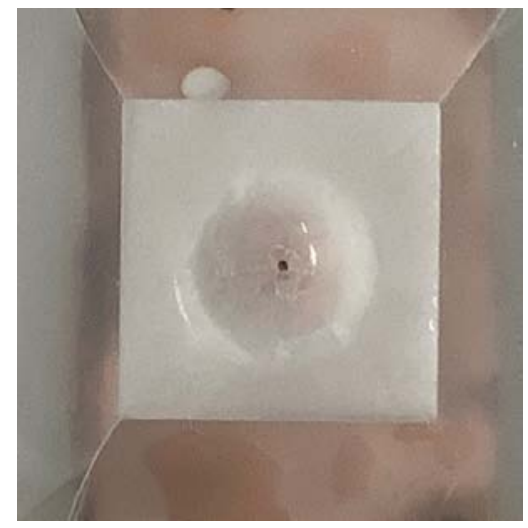

Fig. 3 Breakdown trace.

\section{3. 実験結果}

\section{1 水一デンプン糖混合系の交流絶縁破壊特性}

Fig. 4 および Fig. 5 に液体窒素中での $243 \mathrm{~K}$ および $193 \mathrm{~K}$ で涷結させた氷一デンプン糖混合系の交流絶縁破壊電圧の デンプン濃度特性を示す。図中のマークは交流絶縁破壊電 圧の平均值を, エラーバーは最大值と最小值を, 括弧内の 数字は実験回数を示している。Fig. 4 および Fig. 5 から, デ ンプン糖を混合させた氷の交流絶縁破壊電圧の平均值は, どのデンプン糖濃度においても氷単体のものよりも高く, $20 \mathrm{wt} \%$ の濃度で最も高い交流絶縁破壊電圧を示した。これ らの高い值は, $243 \mathrm{~K}$ 凍結では $0 \mathrm{wt} \%$ の水単体の值の約 2.1 倍であり, $193 \mathrm{~K}$ 凍結では $0 \mathrm{wt} \%$ の水単体の值の約 1.7 倍で あった。また，デンプン糖のみの試料(濃度 $100 \mathrm{wt} \%$ )の交流 絶縁破壊電圧は, 水単体(濃度 $0 \mathrm{wt} \%$ )試料のものと同程度で あることから, 蒸留水とデンプン糖の適切な濃度の混合は 電気絶縁性能を向上させることが示された。

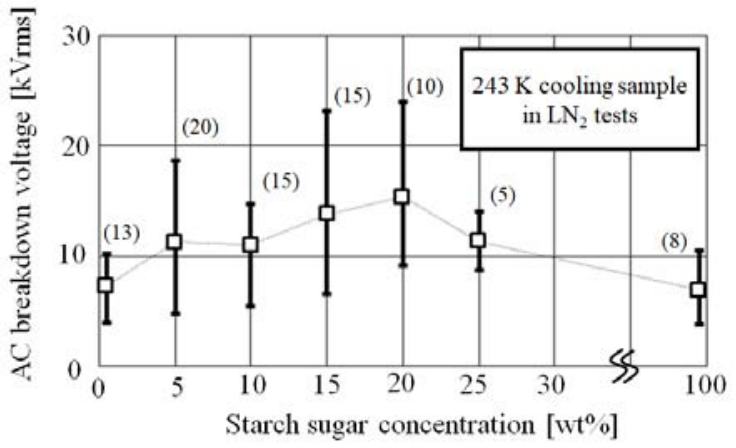

Fig. 4 AC breakdown voltage of a $243 \mathrm{~K}$ cooling icestarch sugar mixed sample as a function of the starch sugar concentration in $\mathrm{LN}_{2}$.

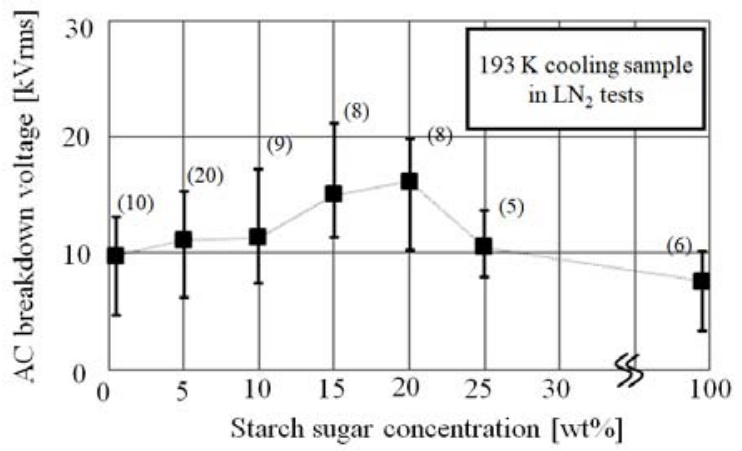

Fig. 5 AC breakdown voltage of a $193 \mathrm{~K}$ cooling icestarch sugar mixed sample as a function of the starch sugar concentration in $\mathrm{LN}_{2}$. 


\section{2 水一デンプン糖混合系の凍結時の温度変化}

冷凍時の試料温度は電極間に挿入した $\mathrm{T}$ 型熱電対および データロガー（GRAPHTEC, midi LOGGER GL240）を用い て測定した。Fig. 6 および Fig. 7 に $243 \mathrm{~K}$ および $193 \mathrm{~K}$ 冷却 におけるデンプン濃度 $0,10,25,100 \mathrm{wt} \%$ 試料の温度変化を 示す。Fig. 8 に試料の凍結過程の模式図を示す。各デンプン 濃度試料の冷却過程を検討するために, 冷却速度を試料温 度が $288 \mathrm{~K}\left(15^{\circ} \mathrm{C}\right)$ に達したときから過冷却解消温度までの 温度低下速度(Fig. 8 中の A から B に要した時間)および凝固 時間を試料の凝固開始点(Fig. 8 中の C) と試料中全物質の凝 固(Fig. 8 中の D)の間の時間とそれぞれ定義した。Fig. 9 お よび Fig. 10 に冷却速度および凝固時間のデンプン糖濃度特 性を示す。

過冷却現象は, 水結晶を生成するために必要な水核が凝 固点より低い温度で生成しているときに発生する。水核が

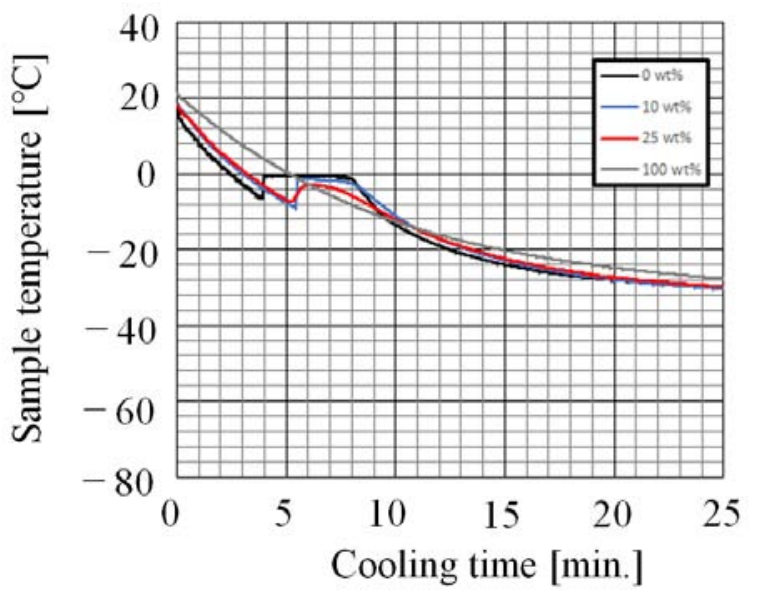

Fig. 6 Temperature of the ice starch sugar mixed system as a function of time in a $243 \mathrm{~K}$ freezer.

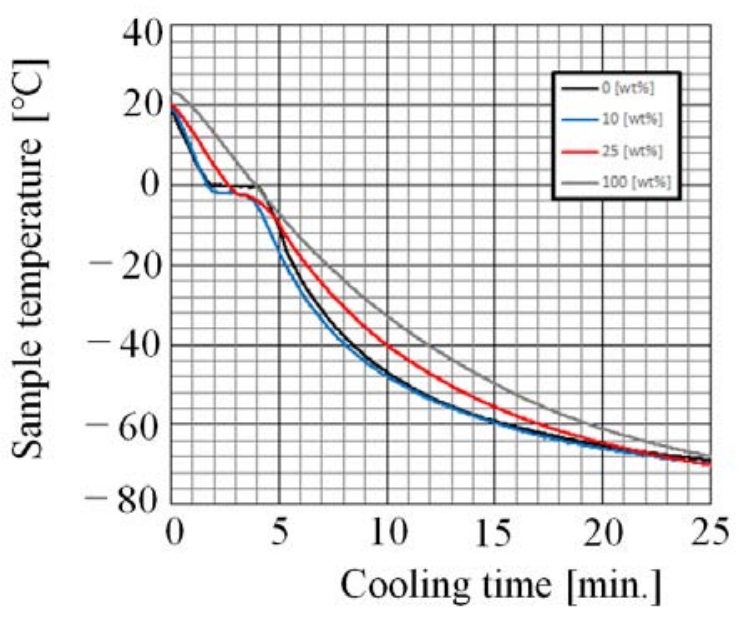

Fig. 7 Temperature of the ice starch sugar mixed system as a function of time in a $193 \mathrm{~K}$ freezer.
形成されると，水結晶が成長し凝固熱が放出される。この 凝固熱によって過冷却解消温度から温度上昇し, 凝固熱放 出完了後に再び温度が低下寸る。 $243 \mathrm{~K}$ 冷却の水溶液の過 冷却解消温度は, $261 \sim 271 \mathrm{~K}\left(-2{ }^{\circ} \mathrm{C} \sim-12{ }^{\circ} \mathrm{C}\right)$ であり, Fig. 7 にも示した通り, $193 \mathrm{~K}$ 冷却では過冷却は生じなかった。 Fig. 9 より冷却速度は, デンプン糖濃度に余り依存しないこ とが示された。凝固時間は, Fig. 10 に示すようにデンプン 糖濃度が高くなるほど短く, 即座に温度が低下した。

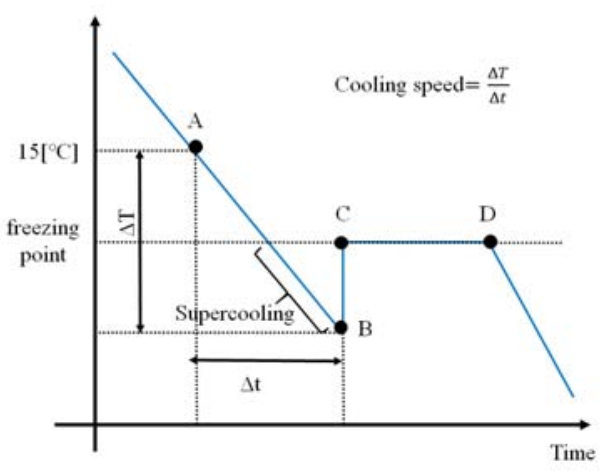

Fig. 8 Schematic diagram of sample temperature change.

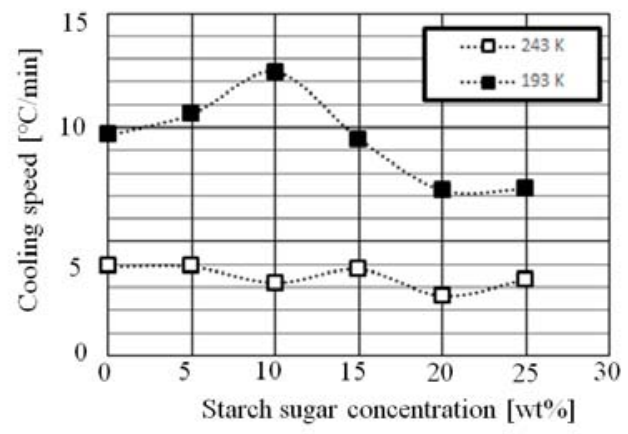

Fig. 9 Cooling speed $(\Delta \mathrm{T} / \Delta \mathrm{t}$ in Fig. 8) of the sample as a function of the starch sugar concentration.

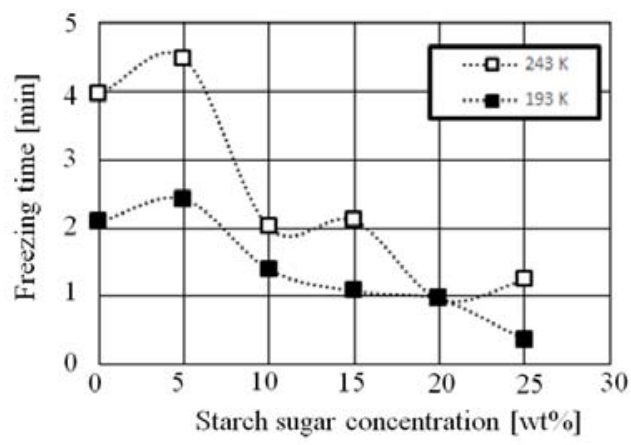

Fig. 10 Freezing time (during $C$ to $D$ in Fig. 8) of the sample as a function of the starch sugar concentration. 


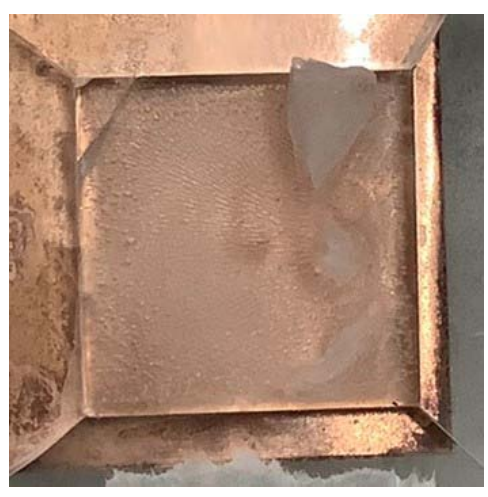

(a) $0 \mathrm{wt} \%$

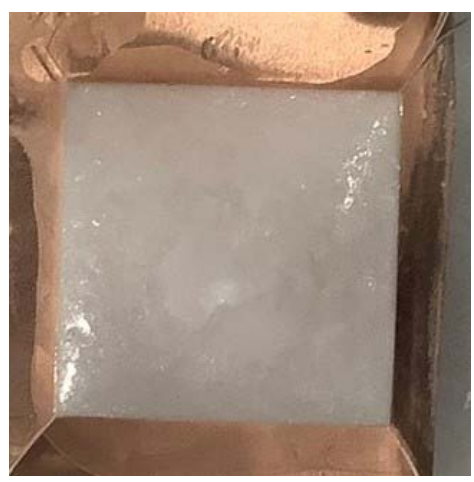

(d) $15 \mathrm{wt} \%$

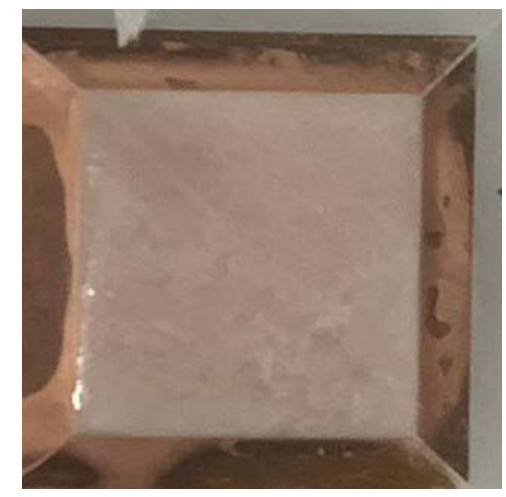

(b) $5 \mathrm{wt} \%$

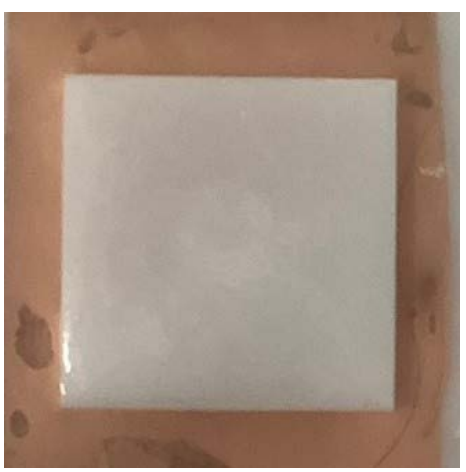

(e) $20 \mathrm{wt} \%$

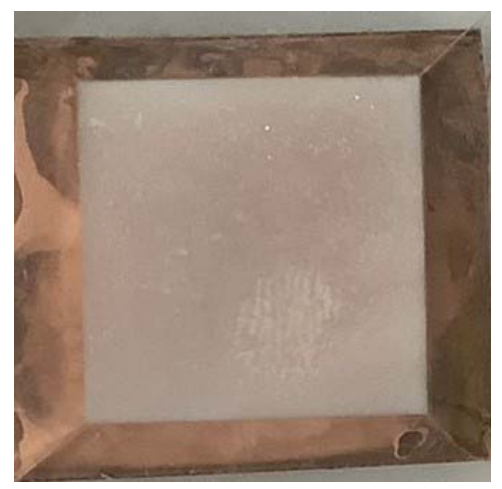

(c) $10 \mathrm{wt} \%$

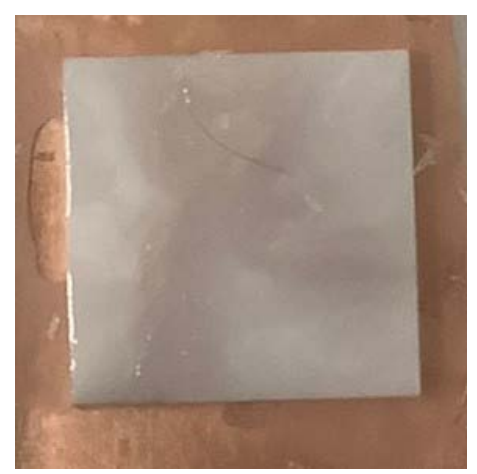

(f) $25 \mathrm{wt} \%$

Fig. 11 Solidification state of the ice-starch sugar mixed system at $243 \mathrm{~K}$.

\section{3 水一デンプン糖混合系の固化状態}

水一デンプン糖混合系の固化状態を観察するため, Fig. 1 の電極系の球電極を取り付けずに試料を冷凍した。Fig. 11 およびFig. 12 に 243 K および $193 \mathrm{~K}$ 凍結後の各濃度試料の 固化状態をそれぞれ示す。Fig. 11 から，デンプン糖濃度が $0 \mathrm{wt} \%$ のきの試料は透明だったが，デンプン糖濃度が高 くなるほど試料が白濁していることがわかる。また， $0 \mathrm{wt} \%$ 以外の試料はシャーベット状に固化していた。0 wt \% の試料は，氷内に多くのボイドが目視で確認できたが，デ ンプン糖混合系試料では目視できるボイドの量が減少した。 デンプン糖混合試料では, 白濁の度合いが均一でなく, 白 濁が濃い部分と薄い部分が存在していた。Fig. 12 から，193 K 凍結後の固化状態は $243 \mathrm{~K}$ の固化状態と同様に濃度が高 くなるほど試料が白濁し, 目視できるボイドの量も減少し た。

\section{4. 考察}

Fig. 4 および Fig. 5 から，濃度 $20 \mathrm{wt} \%$ の水一デンプン糖 混合系の交流絶縁破壊電圧は氷単体のものより高い結果が 示された。 $0^{\circ} \mathrm{C} の$ 時の水の密度は水のものより低いことか ら，氷は寸き間の多い固体であることが知られている 13)。 水にエタノールや糖を入れたとき，エタノールや糖の分子 は水の六方晶内の寸き間に入りこむことが考えられてお り，エタノール濃度が約 $18 \mathrm{wt} \%$ の場合，そのすき間の大部
分はエタノール分子でふさがることが報告されている ${ }^{14) 。 ~}$ 本研究では，デンプン糖の分子が氷分子のすき間を埋める ことで，微小空間での部分放電を抑制し，絶縁性能が向上 したと考えられる。水の絶縁性能の低下の原因として, 水 中のボイドとクラックの存在がある。一般的に水溶液の固 化は水結晶の生成から始まる。そして氷結晶の成長に伴っ てそれ以外の溶質は氷結晶と未固化の水溶液の界面に排出 される。この溶質排出の過程でボイドやクラックの数が減 少し, 部分放電が抑制されたと考えられる。デンプン糖分 子が水の六方晶内に入る現象と水結晶の溶質排出現象の関 連性は不明な点が多い。これらの機構を詳細に検討するこ とで, 水が母体の高性能な極低温絶縁材料の開発が可能と なる。また，本研究では部分放電は測定できていない。今 後, 部分放電を観測することで, 水複合系の絶縁性能向上 機構を検討する必要がある。Fig. 11 および Fig. 12 に示すよ うに，水一デンプン糖混合系にすることにより，試料中の ボイドやクラック発生減少を目視で確認できた。水一デン プン糖混合系の交流絶縁破壊電圧のばらつきは，水単体 $(0$ $\mathrm{wt} \%)$ あいはデンプン糖単体 $(100 \mathrm{wt} \%)$ のものよりも大き い。固化過程において, 排出された溶質は, 界面から水溶 液中に拡散し, 凍結濃縮が生じる。凍結濃縮とは, 水結晶 の生成により水溶液濃度が上昇することである。さらに冷 却を進めると凍結濃縮はより進行し，水溶液はガラス転移 


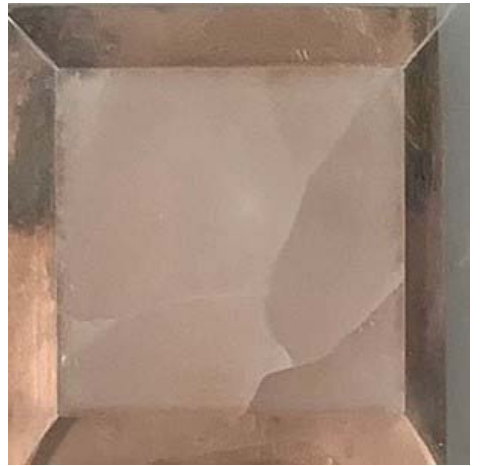

(a) $0 \mathrm{wt} \%$

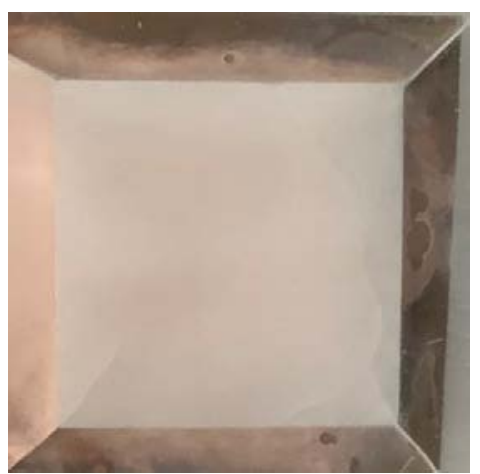

(d) $15 \mathrm{wt} \%$

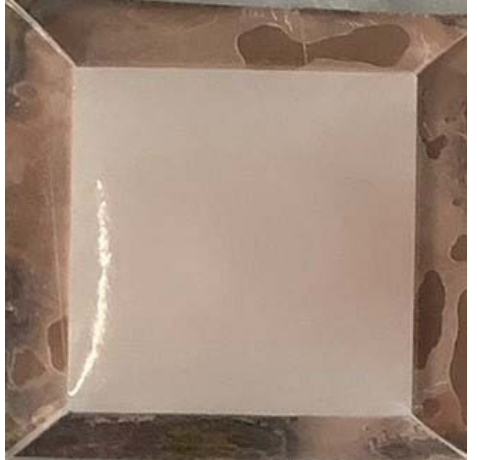

(b) $5 \mathrm{wt} \%$

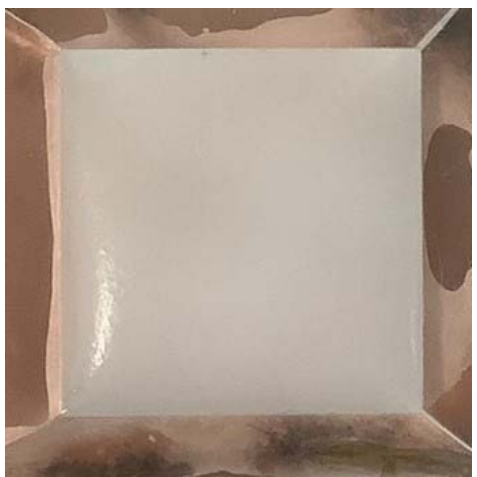

(e) $20 \mathrm{wt} \%$

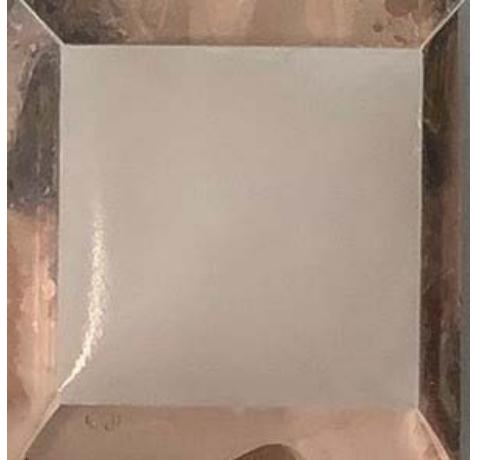

(c) $10 \mathrm{wt} \%$

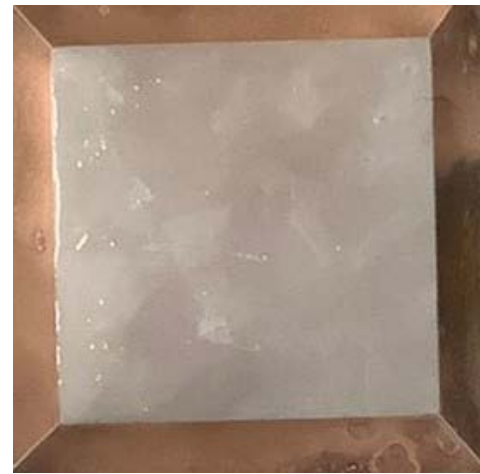

(f) $25 \mathrm{wt} \%$

Fig. 12 Solidification state of the ice-starch sugar mixed system at $193 \mathrm{~K}$.

に必要な温度と濃度に到達する。このことから，氷一デン プン糖試料の固化物は水結晶とガラス転移した混合系水溶 物の複合体であることが考えられる。Fig. 11 および Fig. 12 の固化状態からも，混合系の固化状態がシャーベット状 だったことが確認でき, 結晶状の水結晶と非結晶状の混合 水溶物が混在していることが予想される。そのため，水一 デンプン糖混合系の固化状態は, 蒸留水 $(0 \mathrm{wt} \%)$ やデンプン 糖(100 wt\%)のものよりも複雑であるため, 絶縁破壊電圧の エラーバーが大きくなったことが考えられる。

Fig. 11(f)および Fig. 12(f)の濃度 $25 \mathrm{wt} \%$ のと，固化試料 中の白濁度合いは，他の濃度と比較して不均一であった。 まだら状部分は、氷結晶から排出され析出した溶質部と思 われる。これは, 試料中の水結晶成長および溶質拡散速度 の割合によるものだと考えられる。

本研究にて, 水一 15～20 wt\%のデンプン糖混合系は交 流絶縁破壊特性を向上させることがわかった。上野らは, 固化試料の水結晶状態がその系全体の誘電率に影響を与え ていることを報告している ${ }^{15)}$ 。今後は，単糖のグルコー スや多糖のアミロースを用いて固化状態と誘電絶縁特性の 関係を詳細に検討し，低環境負荷の極低温用電気絶縁材料 の開発に取り組んでいきたい。また，実機を想定した厚さ
数十 $\mathrm{mm}$ 程度の水複合系試料の均一性に及ぼす冷却速度, 冷却時間および糖濃度等の影響を調査する予定である。

\section{5. まとめ}

本研究では，極低温下での低環境負荷電気絶縁材料の開 発を目的とし，水溶性物質である多糖類のデンプン糖に注 目した。そして, 水一デンプン糖混合系の交流絶縁破壊電 圧のデンプン糖濃度特性や固化状態を取得し, 以下の結論 を得た。

(1). $20 \mathrm{wt} \%$ のデンプン糖を混合させた氷の交流絶縁破壊電 圧の平均值は， $243 \mathrm{~K}$ 凍結では氷単体 $(0 \mathrm{wt} \%)$ およびデ ンプン糖単体(100 wt\%)の值の約 2.1 倍であり, $193 \mathrm{~K}$ 凍結では約 1.6 倍であった。それ以外のデンプン糖濃 度での交流絶縁破壊電圧は, 水単体およびデンプン糖 単体のものと同程度であったことから, 蒸留水とデン プン糖の適切な濃度の混合は電気絶縁性能を向上させ ることが示された。

(2). 水一デンプン糖混合系試料の凍結過程では, 過冷却解 消温度は, $243 \mathrm{~K}$ 凍結では 261〜271 K であり, $193 \mathrm{~K}$ 凍結では過冷却は生じなかった。冷却速度はデンプン 
糖濃度に依存せず，凝固時間はデンプン糖濃度が高く なるほど短く, 即座に温度が低下した。

(3). 水単体 $(0 \mathrm{wt} \%)$ 試料の固化物は透明だったが, デンプ ン糖複合系試料では, その濃度が高くなるほど白濁し, シャーベット状に固化していた。氷単体では, 水内に 多くのボイドが目視で確認できたが，デンプン糖混合 系試料では目視できるボイドの量が減少した。これに より複合系試料の電気絶縁破壊特性が向上する可能性 があることが認められた。

\section{参 考 文 献}

1)西嶋茂宏, 西村 新：「小特集磁場閉じ込め核融合炉に向 けた超電導マグネット材料工学 3. 電気絶縁材料」, 核融 合・プラズマ, 83 (2007) 39-43

2) Y. Fujii: "The present conditions of GFRP which aimed at the environmental load reduction," Journal of the Society of Materials Science Japan 57 (2008) 621-625 (in Japanese) 藤井善通：「環境負荷低減を目指した複合材料技術の進展 1 . 環境負荷低減を目指した GFRP の現状」, 材料 57 (2008) 621625

3) Peter V. Hobbs : "Ice physics," Oxford university press, Oxford (2010) 1-837

4) 前野紀一：「水の科学」, 北海道大学図書刊行会, 札幌(1981) $1-234$

5) H. Nakashima, et al.: "Estimation of electrical aging for ice-silica compound insulation," IEEJ Trans. FM 103 (1983) 437-442 (in Japanese)

中島秀樹ら :「シリカ充てん水絶縁の課電寿命の推定」, 電学 論 A103 (1983) 437-442

6) N. Shimizu, et al.: "Dielectric and breakdown properties of ice at temperatures around $-10{ }^{\circ} \mathrm{C}$," IEEJ Trans. FM 104 (1984) 525-530 (in Japanese)

清水教之ら：「-10 ${ }^{\circ} \mathrm{C}$ 付近における水の誘電特性と絶縁破壊 特性」, 電学論 A 104 (1984) 525-530

7) N. Shimizu and Y. Muramoto: "Natural materials adopted for electrical and electronic materials," IEEJ Trans. FM 127 (2008) 429-432 (in Japanese)

清水教之, 村本裕二:「自然材料を電気・電子材料に一誘 電・絶縁材料の場合一」, 電学論 A 127 (2008) 429-432

8) Y. Muramoto, Y. Kishimoto and N. Shimizu: "AC electrical breakdown properties of a kenaf fiber-ice composite system in the cryogenic region," TEION KOGAKU 43 (2008) 138-142 (in Japanese)

村本裕二, 岸本 雄, 清水教之:「極低温領域におけるケナフ 繊維一水複合系の交流電気絶縁破壊特性」, 低温工学 43 (2008) $138-142$

9) Y. Shiji, Y. Muramoto and N. Shimizu: "AC breakdown properties of bamboo pulp-ice composite system at cryogenic temperature," IEEE Trans. Dielect. Elect. Insulation 14 (2007) 296-301

10) R. Tsuchiya, Y. Muramoto and N. Shimizu: "AC breakdown properties of solidified alcohol aqueous-solution,” IEEJ Trans. FM 134 (2014) 154-161 (in Japanese)
土屋龍平, 村本裕二, 清水教之:「固化したアルコール水溶 液の交流絶縁破壊特性」, 電学論 A 134 (2014) 154-161

11) R. Tsuchiya, Y. Muramoto and N. Shimizu: "AC breakdown properties of solidification states of solidified alcohol aqueous solution,” IEEJ Trans. FM 136 (2016) 54-63 (in Japanese) 土屋龍平, 村本裕二, 清水教之:「固化アルコール水溶液の 交流絶縁破壊特性と固化状態」, 電学論 A, 136 (2016) 54-63

12) R. Tsuchiya, Y. Muramoto and N. Shimizu: "AC breakdown properties of cotton fabric-solidified alcohol aqueous solution composite systems at $77 \mathrm{~K}$," TEION KOGAKU 51 (2016) 9-14 (in Japanese)

土屋龍平, 村本裕二, 清水教之: 「77 K における綿布一固化 アルコール水溶液複合系の交流絶縁破壊特性」, 低温工学 51 (2016) 9-14

13) N. Maeno: "Structures and thermal properties of ice and snow," Netsu Bussei, 8 (1994) 250-255 (in Japanese)

前野紀一: 「氷と雪の構造と熱物性」, 熱物性, 4 (1994) 250255

14）上平 恒：「水とはなにかく新装版〉 ミクロに見たそのふ るまい」, B-1646, 講談社, 2009 年

15) S. Ueno, et al.: "Valuation of dielectric properties in freeze concentrated polymer," Trans. of the JSRAE 29 (2012) 365-371 (in Japanese)

上野茂昭ら：「凍結高分子ゲルの水結晶断面画像を用いた凍 結濃縮相の誘電特性評価」, 日本冷凍空調学会論文集 29 (2012) 365-371

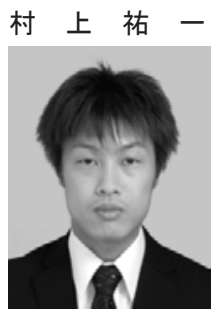

2017 年 3 月名城大学大学院理工学研究科電 気電子・情報 - 材料工学専攻博士後期課程修 了。同年 4 月同大学理工学部電気電子工学科助 教, 現在に至る。主として, 電界による液体殺 菌や低環境負荷の絶縁材料に関寸る研究に従 事。博士 (工学)。IEEE, 電気学会, 静電気学 会会員。

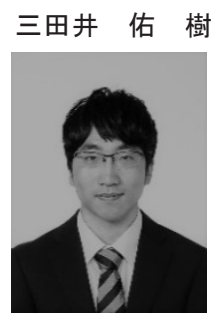

2021 年 3 月名城大学理工学部電気電子工学 科卒業。主として, 極低温電気絶縁材料に関寸 る研究に従事。学士 (工学)。

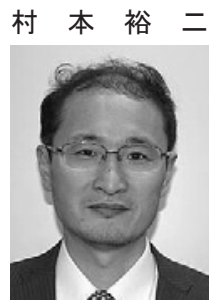

1995 年豊橋技術科学大学大学院工学研究科 博士後期課程修了。豊橋技術科学大学工学部助 手, 名城大学理工学部講師, 同准教授を経て, 2014 年同大学理工学部教授, 現在に至る。高 電界電気現象に関寸る研究に従事。博士（工 学)。低温工学・超電導学会, IEEE, 電気学 会, 静電気学会会員。 